Didenko, I., Puacz-Olszewska, J., Lyeonov, S., Ostrowska-Dankiewicz, A., \&

Ciekanowski, Z. (2020). Social safety and behavioral aspects of populations

financial inclusion: A multicountry analysis. Journal of International Studies, 13(2),

347-359. doi:10.14254/2071-8330.2020/13-2/23

\title{
Social safety and behavioral aspects of populations financial inclusion: \\ A multicountry analysis
}

\author{
Iryna Didenko \\ Department of Economic Cybernetics, Sumy State University, \\ Ukraine \\ i.didenko@uabs.sumdu.edu.ua \\ ORCID 0000-0003-1934-7031 \\ Jolanta Puacz-Olszewska \\ Faculty of Management, Rzeszow University $f$ Technology, \\ Poland \\ j.puacz@prz.edu.pl \\ ORCID 0000-0002-8034-4502
}

\section{Serhiy Lyeonov}

Department of Economic Cybernetics, Sumy State University, Ukraine

S.Lieonov@uabs.sumdu.edu.ua

ORCID 0000-0001-8139-0458

\section{Anna Ostrowska-Dankiewicz}

Faculty of Management, Rzeszow University f Technology,

Poland

adankiew@prz.edu.pl

ORCID 0000-0002-2131-4522

\section{Zbigniew Ciekanowski}

Pope John Paul II State School of Higher Education in Biala

Podlaska, Poland

z.ciekanowski@,dydak.tyka.pswbp.pl

ORCID 0000-0002-0549-894X

Abstract. This article aims to investigate the connection between behavioral aspects of populations financial inclusion and the level of social safety. The study was conducted in several stages: collecting the necessary input, determining The Index of socio-safety, selecting the most relevant factors that characterize the behavioral aspects of financial inclusion, determining the functional relationships between 
financial inclusion. The study involved 26 countries with different levels of economic development, and 18 indicators (10 characterized the behavioral aspects of financial involvement of the population, 8 - the world vectors of social safety). The Index of socio-safety was obtained with the help of PCA. Russian Federation and South Africa have the highest level of The Index among the studied countries. The lowest level of the calculated indicator is in Mozambique and Burkina Faso. Correlation and regression analysis revealed a statistically significant relationship between The Index of socio-safety and an increasing number of ATMs per 100,000 adults, usage of the internet to pay bills or to buy something online and increase the percentage of respondents who report having a credit card.

Keywords: financial inclusion, social safety, population, economic development of the country.

JEL Classification: E58, G21, G18, D11

\section{INTRODUCTION}

The financial sector is a robust set of financial information that requires daily detailed analysis and processing. Financial inclusion, as a part of the formation of the general level of consumers' interests protection in the financial services market, is a driver for social inclusion. The European Microfinance Platform identifies 20 trends that can be used to analyze the population's financial inclusion, which updates the value of data science in its research. It is known that psychological impulses (existing bias, aversion to loss, and cognitive overload) can lead to reckless financial decisions. For members of society in poverty or on the brink of poverty, the consequences of such financial decisions (low economic level, chronic debt, short-term investment) can be devastating.

Many international organizations (World Bank, International Labor Organization, Food, and Agriculture Organization of the United Nations) consider social safety as a set of measures aimed at reducing social and economic risk and vulnerability and reducing overall poverty. Today, social safety includes three vectors: social assistance (publicly provided conditional or unconditional remittances or in-kind transfers, or community service programs); social insurance programs that contribute to specific emergencies that affect the well-being or income of households); labor market protection (provides unemployment benefits, develops skills and trains employees). Social safety refers not only to social development but also to economic transformation (increasing the purchasing power of households and stimulating and growing demand for food and other goods and services). The comprehensive action of social protection measures is aimed at combining programs of subsidies and savings and affects social protection measures. It allows poor people to overcome poverty steadily.

Nowadays, a lot of digital financial services are not incomprehensible, so many financial transactions are conducted through local agency networks. The reason of the low level of financial involvement of the population is not the level of financial literacy, but behavioral aspects (mismatch of certain functions with expectations, misconceptions about the principles of financial product or service, the influence of majority opinion on financial decision-making). Today, more and more people are talking about the true nature of the population's low financial activity. According to the latest data from the World Bank, 69 percent of adults around the world have an account. In the context of global digitalization of financial transactions, this figure should be expected to be higher. 
Many adults in developing countries do not benefit from sophisticated financial instruments, such as automatic payroll deposits, mandatory pension contributions, or default insurance programs that help mitigate the effects of intuitive thinking. All these tools only complicate the financial decision-making process. Therefore, studying the impact of behavioral aspects of financial inclusion on the level of social safety is relevant and needs to be addressed. The aim of the article is to assess the level of connection between behavioral aspects of populations financial inclusion and the level of social safety.

\section{LITERATURE REVIEW}

Financial inclusion of the population determines the degree to which consumers have access to financial products and services. Usually, this concept is considered from three main points: financial literacy, financial security and financial activity. It is an opportunity to have access to branches of banks and other financial institutions, ATMs, self-service terminals, freely to control personal accounts, savings, and the distance to the service unit, trust in financial institutions, operating expenses, document flow. Besides, the works of (Bagmet \& Obeid, 2017), (Bakari et al., 2018), (Buriak et al., 2019), (Caplinska \& Ohotina, 2019), (Greco, 2017), (Kliestik et al., 2020), (Stefko et al., 2019), (Morscher et al., 2017), (Makarenko \& Sirkovska, 2017), (Dave, 2017a; 2017b), (Singh, 2018), (García, 2016) consider financial inclusion as an integral part in the development of "healthy" financial society.

A group of researchers headed by Demirguc-Kunt in their study (Demirguc-Kunt et al., 2017) analyzes the impact of population financial inclusion on economic growth at the household level. Heng (2015) focuses on exploring the impact of new financial services on the financial stability of Bolivia and the financial inclusion of its population. Garcia (2016) investigates the relationship between financial security and affordability by the correlation model based on data from 2008 - 2016 in more than 150 countries. Such scientists as (Grybaitè \& Stankevičienè, 2018), (Khan et al., 2017), (Levchenko et al., 2019), (Mishchuk et al., 2019), (Nocoń \& Pyka, 2019), (Sisodia, 2019), (Vasileva \& Lasukova, 2013), (Vasilyeva et al., 2020), (Grenčiková et al., 2019) used regression-correlation analysis and other methods as the way to process large amounts of financial data in the works.

Many works, in particular, (Bausch, 2019), (Bilan et al., 2019a, 2018), (Brychko \& Olejarz, 2019), (Munk et al., 2017), (Rudiawarni et al., 2020), (Vasilyeva et al., 2016, 2019), (Shvindina, 2019) deal with the study of financial and business cycles based on time series analysis (seasonal, trend, cyclical component separation). Also there are a lot investigations about behavioral aspects in financial inclusion ((Brychko, 2013), (Churilova et al., 2019), (Cortés-Sánchez \& Rivera, 2019), (Djajanto et al., 2019), (Djalilov et al., 2015), (Hadbaa \& Boutti, 2019), (Kaasa, 2019), (Katan et al., 2019), (Kolomiiets \& Petrushenko, 2017), (Matošková, 2019), (Němcová \& Staňková, 2019)) and protection of consumers ((Piatek, 2018), (Poliakh, 2018), (Rehman, 2020), (Shapovalova et al., 2019), (Mihalčová et al., 2018)). Many scientific papers have found that the social safety of the population is also determined by the macroeconomic situation of the country (Aqil et al., 2019), (Bilan et al., 2019b, 2019f), (Logan \& Esmano, 2017), (Próchniak \& Szyszko, 2019), (Packard et al., 2019); alternative factors related to the development of other sectors of the economy (industry, banking, investment, education) (Bilan et al., 2019c); (Buriak, 2015), (Ch \& Semenog, 2017), (Klimontowicz, 2019), (Leonov et al., 2014, 2019), (Pryima et al., 2018), (Trębska, 2018); socio-economic challenges (Gupta, 2017), (Korcsmáros \& Šimova, 2018), (Kostyuchenko et al., 2018), (Louis, 2017), (Lyeonov \& Liuta, 2016). 


\section{METHODOLOGY}

The methodology of research involves the following steps:

- collection of necessary input information;

- determination of the Index of socio-safety;

- selection of the most relevant factors that characterize the behavioral aspects of financial inclusion;

- identification of functional relationships between The Index of socio-safety and indicators that characterize the key behavioral issues of financial inclusion.

Information from the World Bank databases was used as input variables in the article: Coverage of Social Protection and Labor programs by harmonized program category and Global Financial Inclusion for 26 countries with different economic development levels. The input indicators and their symbols are presented in the Table 1 of Annexes. From the given data, ten indicators (x1-x10), which characterize the behavioral aspects of financial inclusion. The choice of such a set of indicators to assess the behavioral aspects of financial inclusion is due to the openness of information from the international database The Global Findex, which allows for multicountry analysis of the financial inclusion. Eight indicators of social safety (Y1-Y8) were selected according to the world vectors of social safety (social insurance, social assistance, labor market). The method developed in this article is implemented on the example of data for 2014, as it is for this period that we have available data.

It is proposed to express the Index of socio-safety through the integral index determined by the principal component method by adjusting the inputs (Y1-Y8) by the weighting coefficients wi obtained from the following formula (1):

$$
w_{i}=\frac{f_{i} d_{k}}{\sum_{k} f_{i} d_{k}}
$$

where:
$w_{i}$ - weight $i$ variables;
$f_{i}$ - factor load $i$ variables;
$d_{k}$ - share of total variance.

The integral index is determined by the formula (2):

$$
I=\sum \bar{y}_{i j} w_{i}
$$

where:

$\bar{y}_{i j}$ - normalized indicator value.

Normalization for the stimulants is carried out according to the formula (3):

$$
\bar{y}_{i j}=\frac{y_{i j}-y_{\min }}{y_{\max }-y_{\min }}
$$

For the destimulants (4):

$$
\bar{y}_{i j}=1-\frac{y_{i j}-y_{\min }}{y_{\max }-y_{\min }}
$$


In our case, all indicators are stimulants.

The selection of the most relevant factors that characterize the behavioral aspects of the financial inclusion of the population will be made using Principal Component Analysis. Principal Component Analysis, PCA is at the part of factor analysis. Factor analysis is used to solve two main problems: reducing the number of variables (data reduction); defining the structure of relationships between variables, their classification.

PCA allows to identify a number of components (factors) that explains all the variance and correlations of the initial values. The selected components (their number can be both set individually and programmatically obtained) are ranked in descending order of the proportion of total variance explained by each component. It is generally accepted that those components that account for more than $70 \%$ of the total variance can be called the most influential among the entire sample. The principle of selecting is next - the first component is to choose exactly the direction in the space of initial variables, in which the set of objects (points) under study has the greatest variation (variance). Each subsequent component is calculated to have its direction parallel to the first component and to account for as much of the residual dispersion as possible. This process continues until all the components that determine $100 \%$ of the variance of the studied variables are found. In addition, it is possible to determine the required number of factors by using a scree plot, where, on the basis of the eigenvalues of factors, Cattell (1966) suggested to find a place on the graph when the velocity of decreasing eigenvalues, when looking at the graph from left to right, decreases significantly. Anything left on the right side of the checkpoint is called "debris" that does not have a significant effect on the result. After determining the optimal number of factors, it is necessary to analyze the eigenvalues of the factors - these are the variances that are allocated to each of the factors.

Correlation analysis is required before identifying functional relationships between variables. It allows to determine the closeness and direction of the relationship between variables. Formalization of functional dependencies between The Index of socio-safety and indicators characterizing the behavioral aspects of financial inclusion will be carried out using regression analysis. The selection of the most relevant factors that characterize the behavioral issues of the financial inclusion of the population will be made using PCA.

It is necessary to take into account the values of the main parametric criteria, which can be used to assess the accuracy and significance of the model results. The obtained model will be evaluated according to the following criteria: coefficient of determination, Fisher's, and Student's tests. The ratio of determination R2 shows what part of the performance indicator's variation is related to the variety of the factor indicators. Fisher's (F-test) and Student's (t-test) criteria can answer the significance of the obtained results. The F-criterion's actual value is compared with its tabular value at given degrees of freedom and level of significance. If the condition is met, under which $\mathrm{F}_{\text {crit }}>\mathrm{F}_{\text {tabl. }}$. And the probability $\mathrm{p}$ is less (equal) than 0,05 (at a given confidence level of 0,95 ), the hypothesis of the significance of the relationship between the dependent and factor variables is confirmed, if on the contrary - is rejected. In the case of the Student's $\mathrm{t}$-test, the calculated value of the t-test is compared with the tabular value, which is selected from the corresponding statistical tables at a certain level of significance and degrees of freedom. If $t_{\text {tabl }}<t_{\text {crit, }}$ then we can talk about the significance of the coefficient of determination. In the case of the obtained coefficients of the equation, this equality, as well as the probability value $\mathrm{p}$, for each value of the criterion, which must also be less (equal) than 0,05 (for a given confidence level of 0,95 ). It tells that they are significant in models and different from 0 . All identified stages of the study were implemented using STATISTICA software. 


\section{EMPIRICAL RESULTS AND DISCUSSION}

As a result of using PCA The Index of socio-safety is presented in the Table 2 of Annexes and in the cartogram (Fig 1).

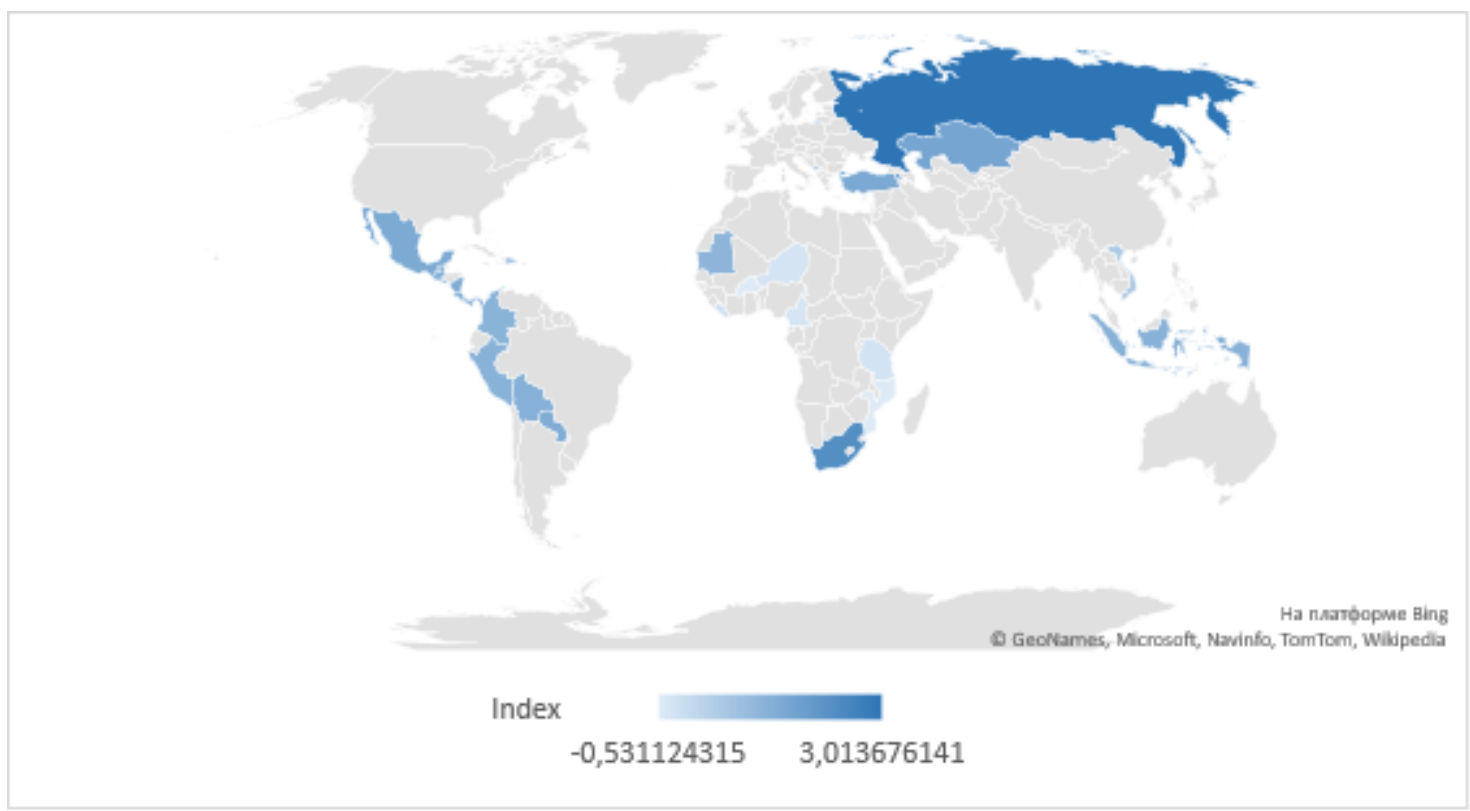

Figure 1. The Index of socio-safety in the world

Source: Authors' results

In this case we can see that Russian Federation and South Africa have the first position in the rating of The Index of socio-safety. Other countries have much smaller the level of of socio-safety.

As a result of the next step, 6 from 10 inputs $(\mathrm{x} 1-\mathrm{x} 10)$ were selected. The number of selected factors and factor loadings for each indicator are presented in the Table 3.

Table 3

Factor loadings

\begin{tabular}{|c|c|c|c|}
\hline \multirow{2}{*}{ Legend } & \multicolumn{3}{|c|}{ Factors } \\
\cline { 2 - 4 } & Factor 1 & Factor 2 & Factor 3 \\
\hline $\mathrm{x} 1$ & $-0,451$ & 0,644 & 0,025 \\
\hline $\mathrm{x} 2$ & $-0,833$ & 0,406 & $-0,040$ \\
\hline $\mathrm{x} 3$ & $-0,743$ & $-0,140$ & 0,328 \\
\hline $\mathrm{x} 4$ & $-0,542$ & $-0,405$ & 0,353 \\
\hline $\mathrm{x} 5$ & $-0,815$ & $-0,174$ & 0,011 \\
\hline $\mathrm{x} 6$ & $-0,569$ & $-0,468$ & $-0,198$ \\
\hline $\mathrm{x} 7$ & 0,288 & 0,186 & 0,615 \\
\hline $\mathrm{x} 8$ & $-0,882$ & $-0,061$ & 0,174 \\
\hline $\mathrm{x} 9$ & $-0,893$ & $-0,180$ & $-0,095$ \\
\hline $\mathrm{x} 10$ & $-0,868$ & 0,375 & $-0,165$ \\
\hline
\end{tabular}

Source: Authors' results.

As we can see, from the results, the variables $\mathrm{x} 2, \mathrm{x} 3, \mathrm{x} 5, \mathrm{x} 8 \mathrm{-}-\mathrm{x} 10$ are the most relevant in the study. Before including them in the process of determining the functional relationships with The Index of socio- 
safety, we will conduct a correlation analysis to select those indicators of financial inclusion that have the closest relationship with The Index.

The result of the correlation analysis is the correlation matrix and the scattering matrix (Fig. 2).

\begin{tabular}{l|c|c|c|c|c|c|c|}
\cline { 2 - 7 } & $Y$ & $x 2$ & $x 3$ & $x 5$ & $x 8$ & $x 9$ & $x 10$ \\
\hline$Y$ & 1,000000 & 0,195984 & 0,692467 & 0,249860 & 0,427406 & 0,421611 & 0,279503 \\
\hline$x 2$ & 0,195984 & 1,000000 & 0,478639 & 0,596055 & 0,653023 & 0,639135 & 0,921919 \\
\hline$x 3$ & 0,692467 & 0,478639 & 1,000000 & 0,472046 & 0,705310 & 0,585116 & 0,543892 \\
\hline$x 5$ & 0,249860 & 0,596055 & 0,472046 & 1,000000 & 0,720524 & 0,800735 & 0,642433 \\
\hline$x 8$ & 0,427406 & 0,653023 & 0,705310 & 0,720524 & 1,000000 & 0,840130 & 0,708854 \\
\hline$x 9$ & 0,421611 & 0,639135 & 0,585116 & 0,800735 & 0,840130 & 1,000000 & 0,680723 \\
\hline$x 10$ & 0,279503 & 0,921919 & 0,543892 & 0,642433 & 0,708854 & 0,680723 & 1,000000 \\
\hline
\end{tabular}

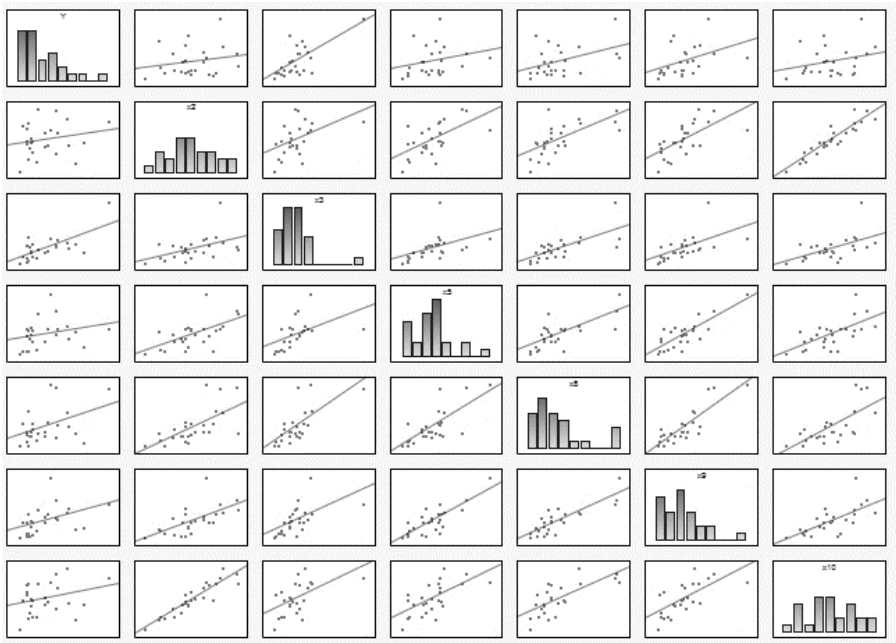

Figure 2. Results of the correlation analysis

Source: Authors' results.

To formalize the relationship between The Index of socio-safety and indicators of financial inclusion, multifactor regression model is constructed, where the integral index The Index $(Y)$ will be as the dependent variable. The indices obtained in the results of PCA and correlation analysis (x3, x8, x9), which will act as independent variables. The obtained simulation parameters are presented in the table 4.

Table 4

Results of modeling

\begin{tabular}{|l|l|l|l|}
\hline \multicolumn{1}{|c|}{ Variables } & \multicolumn{1}{c|}{ Parameters } & \multicolumn{1}{c|}{ t-crit } & p-level \\
\hline free term & 0,075 & 4,849 & $0,000^{* *}$ \\
\hline X3 & 0,670 & 3,228 & $0,001^{* *}$ \\
\hline X8 & $-0,119$ & $-5,006$ & $0,005^{* *}$ \\
\hline X9 & 0,217 & 7,838 & $0,001^{* *}$ \\
\hline \multicolumn{2}{|c|}{$\mathrm{R}^{2}=0,62$} \\
\hline \multicolumn{2}{|c|}{$\mathrm{F}=8,07 ; \mathrm{p}-$ level $=0,0008$} \\
\hline
\end{tabular}

Source: Authors' results ** indicates significance level at 0.05 level

The results of regression are next:

- increasing of the ATMs per 100,000 adults per unit causes increasing of The Index of socio-safety by 0,670 ;

- $\quad$ usage of the internet to pay bills or to buy something online decreases The Index of socio-safety by 0,119 ; 
- increasing of the percentage of respondents, who report having a credit card causes increasing of The Index of socio-safety index by 0,217 .

The quality of the calculations is confirmed by the high value of the coefficient of determination and the level of $\mathrm{p}$ which is less than 0,05 .

As we can see, the result of the study shows the presence of a close functional relationship between The Index of socio-safety and indicators of financial inclusion, which are characterized by behavioral aspects. $62 \%$ of the change in The Index is due to changes in these indicators of financial inclusion. The negative impact on The Index of internet usage to pay bills or to buy something online is explained by insufficient regulatory support for the regulation of financial Internet services.

\section{CONCLUSION}

Formalization of the functional dependence between The Index of socio-safety and behavioral aspects of financial inclusion was carried out in several steps: a collection of necessary input information, determination of The Index of socio-safety, selection of the most relevant factors characterizing behavioral aspects of financial inclusion, determination of functional connections between The Index of socio-safety and indicators that describe the critical behavioral issues of financial inclusion of the population. Using PCA, The Index of socio-safety was obtained: Russian Federation and South Africa have the highest level of The Index of socio-safety among 26 countries with different levels of income. The lowest level of the calculated indicator is in Mozambique and Burkina Faso. Correlation and regression analysis revealed the presence of a statistically significant relationship between The Index of socio-safety and increasing the ATMs per 100,000 adults, usage of the internet to pay bills, or to buy something online and increasing the percentage of respondents who report having a credit card. Taking into account the obtained results will create a basis for reforming the social safety sector of consumers in the financial services market.

\section{ACKNOWLEDGEMENT}

The survey was supported by the Ministry of Education and Science of Ukraine and performed the results of the projects $0118 \mathrm{U} 003569$ and $0120 \mathrm{U} 102001$.

\section{REFERENCES}

Aqil, M., Ahmed, R. R., Vveinhardt, J., \& Streimikiene, D. (2019). Factors influencing the profitability of heavy vehicle industry: a case of Pakistan. Montenegrin Journal of Economics, 15(1), 61-72. https://10.14254/1800-5845/2019.15$\underline{1.5}$.

Bagmet, K., \& Obeid, H. (2017). Financing social protection in Ukraine and the European Union: current situation and prospects. SocioEconomic Challenges, 1(1), 54-59. https://10.21272/sec.2017.1-06.

Bakari, I. H., Idi, A., \& Ibrahim, Y. (2018). Innovation Determinants of Financial Inclusion in Top Ten African Countries: a System GMM Approach. Marketing and Management of Innovations, 4, 98-106. http://DOI.org/10.21272/mmi.2018.4-09.

Bausch, R. D. (2019). Social capital and the cyclicality of government expenditure. International Journal of Trade and Global Markets, 12(3-4), 250-259. doi: 10.1504/IJTGM.2019.101544.

Bilan, Y., Brychko, M., Buriak, A., \& Vasilyeva, T. (2019a). Financial, business and trust cycles: The issues of synchronization. Zbornik Radova Ekonomskog Fakultet an Rijeci, 37(1), 113-138. doi: https://DOI.org/10.18045/zbefri.2019.1.113.

Bilan, Y., Lyeonov, S., Lyulyov, O., \& Pimonenko, T. (2019b). Brand management and macroeconomic stability of the country. Polish Journal of Management Studies, 19(2), 61-74. doi: 10.17512/pjms.2019.19.2.05. 
Bilan, Y., Lyeonov, S., Vasylieva, T., \& Samusevych, Y. (2018). Does tax competition for capital define entrepreneurship trends in Eastern Europe?. Online Journal Modelling the New Europe, 27(1), 34-66. doi: 10.24193/OJMNE.2018.27.02.

Bilan, Y., Rubanov, P., Vasylieva, T., \& Lyeonov, S. (2019c). The influence of industry 4.0 on financial services: Determinants of alternative finance development. Polish Journal of Management Studies, 19(1), 70 - 93. doi: 10.17512/pims.2019.19.1.06.

Bilan, Y., Vasilyeva, T., Lyulyov, O., \& Pimonenko, T. (2019f). EU vector of Ukraine development: linking between macroeconomic stability and social progress. International Journal of Business \& Society, 20(2), 433 - 450.

Brychko, M. M. (2013). Governance of stakeholder's financial relationships: Evidence fom Ukrainian banking sector. Corporate Ownership and Control, 11(1), 706-714.

Brychko, M., \& Olejarz, T. (2019). Trust cycle of the finance sector and its determinants: The case of Ukraine. Journal of International Studies, 12(4), 300 - 324. doi: 10.14254/2071-8330.2019/12-4/20.

Buriak, A., Lyeonov, S., \& Vasylieva, T. (2015). Systematically Important Domestic Banks: An Indicator-Based Measurement Approach for the Ukrainian Banking System. Prague Economic Papers, (6), 715-728. doi: $10.18267 /$ i.pep. 531 .

Buriak, A., Vozńáková, I., Sułkowska, J., \& Kryvych, Y. (2019). Social trust and institutional (Bank) trust: Empirical evidence of interaction. Economics \& Sociology, 12(4), 116-332. doi: 10.14254/2071-789X.2019/12-4/7.

Caplinska, A., \& Ohotina, A. (2019). Analysis of financial literacy tendencies with young people. Entrepreneurship and Sustainability Issues, 6(4), 6. doi: https://DOI.org/10.9770/jesi.2019.6.4(13)

Ch, A. R., \& Semenog A.Y. (2017). Non-bank financial institutions activity in the context of economic growth: crosscountry comparisons. Financial Markets, Institutions and Risks, 1(2), 39-49. doi: 10.21272/fmir.1(2).39-49.2017.

Churilova, E., Salin, V., Shpakovskaya, E., \& Sitnikova, O. (2019). Influence of world social and economic indicators' interlinkage on the development of human potential. Journal of International Studies, 12(4), 79 - 99. DOI: $10.14254 / 2071-8330.2019 / 12-4 / 6$

Cortés-Sánchez, J. D., \& Rivera, L. (2019). Mission statements and financial performance in Latin-American firms. Business: Theory and Practice, 20, 270-283. doi: https://DOI.org/10.3846/btp.2019.26.

Dave, H. (2017a). An Inquiry on Social Issues - Part 1. Business Ethics and Leadership, 1(2), 78 - 87. doi: 10.21272/bel.1(2). $78-88.2017$.

Dave, H. (2017b). An Inquiry on Social Issues - Part 2. Business Ethics and Leadership, 1(3), 45 - 63. doi: 10.21272/bel.1(3).45-63.2017.

Demirguc-Kunt, A., Klapper, L., \& Singer, D. (2017). Financial inclusion and inclusive growth: A review of recent empirical the World Bank. Retrieved from URL: http://documents.worldbank.org/curated/en/403611493134249446/pdf/WPS8040.pdf.

Djajanto, L., Afiatin, Y., \& Haris, Z. A. (2019). The impact of relationship marketing on customer value, satisfaction and loyalty: evidence from banking sector in Indonesia. International Journal of Economic Policy in Emerging Economies, 12(2), 207-214. doi: 10.1504/IJEPEE.2019.099695

Djalilov, K., Vasylieva, T., Lyeonov, S., \& Lasukova, A. (2015). Corporate social responsibility and bank performance in transition countries. Corporate Ownership and Control, 13(1CONT8), 879-888. doi: $10.22495 / \operatorname{cocv} 13 i 1 \mathrm{c} 8 \mathrm{p} 7$.

García, M. J. R. (2016). Can financial inclusion and financial stability go hand in hand. Economic Issues, 21(2), 81-103.

Greco, F. (2017). The analysis of choice in the decision-making process of the agents. Business ethics and leadership, (1, Issue 4), 22-27. doi: 10.21272/bel.1(4).22-27.2017

Grenčíková, A., Bilan, Y., Samusevych, Y., \& Vysochyna, A. (2019). Drivers and inhibitors of entrepreneurship development in central and eastern European countries. In Proceedings of the 33rd International Business Information Management Association Conference, IBIMA (pp. 2536-2547).

Grybaite, V., \& Stankevičienė, J. (2018). An empirical analysis of factors affecting sharing economy growth. Oeconomia Copernicana, 9(4), 635-654. doi: https://DOI.org/10.24136/oc.2018.031.

Gupta, R. (2017). Socioeconomic challenges and its inhabitable global illuminations. SocioEconomic Challenges, 1(1), 8185. doi: $10.21272 / \mathrm{sec} .2017 .1-10$. 
Hadbaa, H., \& Boutti, R. (2019). Behavioral Biases Influencing the Decision Making of Portfolio Managers of Capital Securities and Traders in Morocco. Financial Markets, Institutions and Risks, 3(1), 92-105. doi: http://DOI.org/10.21272/fmir.3(1).92-105.2019.

Heng, D. (2015). Impact of the new financial services law in bolivia on financial stability and inclusion. IMF Working paper, 15/ 267. DOI:10.5089/9781513598420.001

Kaasa, A. (2019). Determinants of individual-level social capital: Culture and personal values. Journal of International Studies, 12(1), 9-32. doi: 10.14254/2071- 8330.2019/12-1/1

Katan, L.; Masiuk, I.; Oliynik, T.; Oliynik, O., \& Zablotskyi, V. (2019). Ensuring complex security of the financial flows movement in the national economy system. Journal of Security and Sustainability Issues, 9(1): 39-50. doi: http:// doi.org/10.9770/jssi.2019.9.1(4).

Khan, K., Qingyang, W., \& Khurshid, A. (2017). Causal relationship between monetary policy and the stock market: a bootstrap rolling window approach. Financial Markets, Institutions and Risks, 1(4), 5-15. doi: 10.21272/fmir.1(4).515.2017.

Kliestik, T., Valaskova, K., Lazaroiu, G., Kovacova, M., \& Vrbka, J. (2020). Remaining Financially Healthy and Competitive: The Role of Financial Predictors. Journal of Competitiveness, 12(1), 74-92. doi: 10.7441/joc.2020.01.05

Klimontowicz, M. (2019). The role of banks innovativeness in building sustainable market efficiency: the case of Poland. Entrepreneurship and Sustainability Issues, 7(1), 525-539.doi: doi: 10.9770/jesi.2019.7.1(37)

Kolomiiets, U., \& Petrushenko, Y. (2017). The human capital theory. Encouragement and criticism. SocioEconomic Challenges, 1, Iss. 1, 77-80. doi: 10.21272/sec.2017.1-09.

Korcsmáros, E., \& Šimova, M. (2018). Factors affecting the business environment of SMEs in Nitra region in Slovakia. Oeconomia Copernicana, 9(2), 309-331. doi: https://doi.org/10.24136/oc.2018.016.

Kostyuchenko, N., Starinskyi, M., Tiutiunyk, I., \& Kobushko, I. (2018). Methodical Approach to the Assessment of Risks Connected With the Legalization of the Proceeds of Crime. Montenegrin Journal of Economics, 14(4), 23-43. doi: $10.14254 / 1800-5845 / 2018.14-4.2$.

Leonov, S., Frolov, S., \& Plastun, V. (2014). Potential of institutional investors and stock market development as an alternative to households' savings allocation in banks. Ekonomichniy chasopys-XXI, 11-12, 65-68. Retrieved from URL: http://soskin.info/userfiles/file/2014/11-12 2014/Leonov Frolov Plastun.pdf.

Leonov, S., Yarovenko, H, Boiko, A.,. \& Dotsenko, T. (2019). Information system for monitoring banking transactions related to money laundering. CEUR Workshop Proceedings, 2422, 297-307. Retrieved from URL: http://ceurws.org/Vol-2422/paper24.pdf.

Levchenko, V., Boyko, A., Bozhenko, V., \& Mynenko, S. (2019). Money laundering risk in developing and transitive economies: analysis of cyclic component of time series. Business: Theory and Practice, 20, 492-508. doi: doi.org/

10.3846/btp.2019.46.

Logan, W., \& Esmanov, O. (2017). Public financial services transparency. Business Ethics and Leadership, Vol. 1, Issue 2, 62-67. doi: 10.21272/bel.1(2).62-67.2017.

Louis, R. (2017). A new economic order for global prosperity. SocioEconomic Challenges, 1, Iss. 2, 52-58. doi: $10.21272 /$ sec.1(2).52-59.2017.

Lyeonov, S., \& Liuta, O. (2016). Actual problems of finance teaching in Ukraine in the post-crisis period. The Financial Crisis, 145-152. doi: 10.1007/978-3-319-20588-5 8.

Makarenko, I. O., \& Sirkovska, N. (2017). Transition to sustainability reporting: evidence from EU and Ukraine. Business Ethics and Leadership, Volume 1, Issue 1, 16 - 24. doi: 10.21272/bel.2017.1-02.

Matošková, J. (2019). Why employees share their knowledge. Business Administration and Management, 22 (2), 83-96. doi: $10.15240 / \mathrm{tul} / 001 / 2019-2-006$

Mihalčová, B., Gallo, P., \& Štofová, L. (2018). Gender stereotypes at managerial positions in selected public institution. Administration \& Public Management Review, 30, 96 - 108. doi: 10.24818/amp/2018.30-07

Mishchuk, H., Samoliuk, N., \& Bilan, Y. (2019). Measuring social justice in the light of effectiveness of public distributive policy. Administration \& Public Management Review, 32, 63 - 76. doi: 10.24818/amp/2019.32-05.

Morscher, C., Horsch A., \& Stephan J. (2017). Credit Information Sharing and Its Link to Financial Inclusion and Financial Intermediation. Financial Markets, Institutions and Risks 1(1), 22-33. doi: 10.21272/fmir.1(3).22-33.2017. 
Munk, M., Pilkova, A., Benko, L., \& Blažeková, P. (2017). Pillar 3: market discipline of the key stakeholders in CEE commercial bank and turbulent times. Journal of Business Economics and Management, 18(5), 954-973. doi: $\underline{10.3846 / 16111699.2017 .1360388}$

Němcová, J., \& Staňková, P. (2019). Factors influencing consumer behaviour of generation Y on the Czech wine market. Marketing and Trade, 4, XXII, 145 - 161. doi: 10.15240/tul/001/2019-4-010.

Nocoń, A., \& Pyka, I. (2019). Sectoral analysis of the effectiveness of bank risk capital in the Visegrad Group countries. Journal of Business Economics and Management, 20(3), 424-445. doi: 10.3846/jbem.2019.9606.

Packard, T., Gentilini, U., Grosh, M., O’Keefe, Ph., Palacios, R., Robalino, R., \& Santos, I. (2019). Protecting All Risk Sharing for a Diverse and Diversifying World of Work. Human Development Perspectives. Washington, DC: World Bank, 293. doi: 10.1596/978-1-4648-1427-3.

Piatek, T. (2018). Work Safety Management - Social and Educational Context. Marketing and Management of Innovations, 4, 66-72. doi: http://doi.org/10.21272/mmi.2018.4-06.

Poliakh, S. (2018). The consumer protection as a driver of innovative development: case study for consumers of financial services. Marketing and Management of Innovations, 2, 378-387. doi: 10.21272/mmi.2018.2-29.

Próchniak, M., \& Szyszko, M. (2019). The similarity of European central banks in terms of transparency and effectiveness. Equilibrium. Quarterly Journal of Economics and Economic Policy, 14(3), 385-404. doi: $10.24136 /$ eq.2019.018

Pryima, S., Dayong, Y., Anishenko, O., Petrushenko, Y., \& Vorontsova, A. (2018). Lifelong learning progress monitoring as a tool for local development management. Problems and Perspectives in Management, 16(3), ap1-13. doi: $10.21511 / \mathrm{ppm} .16(3) \cdot 2018.01$

Rehman, A. (2020). Innovation and Management by Regional Rural Banks in Achieving the Dream of Financial Inclusion in India: Challenges and Prospects. Marketing and Management of Innovations, 1, 222-234. doi: http://doi.org/10.21272/mmi.2020.1-18.

Rudiawarni, F. A., Narsa, I. M., \& Tjahjadi, B. (2020). Are emotions exacerbating the recency bias?: An experimental study. International Journal of Trade and Global Markets, 13(1), 61-70. doi: https://DOI.org/10.1504/IJTGM.2020.104913.

Shapovalova, I., Piiurenko, I., Husarina, N., Petrovska, S., \& Kravchenko, M. (2019). Process Factors of System Security of Trading Enterprises. Journal of Security \& Sustainability, Issues, 9(1), 211 - 225. doi: http://doi.org/10.9770/jssi.2019.9.1(16).

Shvindina, H. (2019). Coopetition as an emerging trend in research: perspectives for safety \& security. Safety, 5(3), 61. doi: https://DOI.org/10.3390/safety5030061.

Singh, S. N. (2018). Regional Disparity and Sustainable Development in North-Eastern States of India: A Policy Perspective. SocioEconomic Challenges, 2(2), 41-48. doi: 10.21272/sec.2(2).41-48.2018.

Sisodia, G. S., Ibanez, A., \& Venugopalan, M. (2019). The economic uncertainty via coups on Fijian economic growth: modelling the effect over varying sample sizes and periods. International Journal of Economic Policy in Emerging Economies, 12(6), 578-605. doi: 10.1504/IJEPEE.2019.105202.

Stefko, R., Jencova, S., Vasanicova, P., \& Litavcova, E. (2019). An evaluation of financial health in the electrical engineering industry. Journal of Competitiveness, 11(4), 144 - 160. doi: https://DOI.org/10.7441/joc.2019.04.10.

Trębska, J. (2018). Polish households' savings in the financial intersectoral linkages. Equilibrium. Quarterly Journal of Economics and Economic Policy, 13(2), 307-329. doi: 10.24136/eq.2018.016.

Vasileva, T., \& Lasukova, A. (2013). Empirical study on the correlation of corporate social responsibility with the banks efficiency and stability. Corporate ownership \& Control, 10(4), 86 - 93. doi: 10.22495/cocv10i4art7.

Vasilyeva, T., Bilan, S., Bagmet, K., \& Seliga, R. (2020). Institutional development gap in the social sector: Crosscountry analysis. Economics \& Sociology, 13(1), 271 - 294. doi: 10.14254/2071-789X.2020/13-1/17.

Vasilyeva, T., Kuzmenko, O., Bozhenko, V., \& Kolotilina, O. (2019). Assessing the dynamics of bifurcation transformations in the economy. SHS Web of Conferences, Vol. 65, 04006, 1 - 6. doi: $10.1051 /$ shsconf $/ 20196504006$.

Vasilyeva, T., Sysoyeva, L., \& Vysochyna, A. (2016). Formalization of factors that are affecting stability of Ukraine banking system. Risk governance \& control: financial markets \& institutions, 6(4), 7-11. doi: 10.22495/rcgv6i4art1. 


\section{ANNEXES}

Table 1

Input variables

\begin{tabular}{|c|c|c|c|}
\hline No & Name of variable & Sense of variable & Legend \\
\hline 1 & Financially literacy & Adults who are financially literate $(\%)$ & $\mathrm{x} 1$ \\
\hline 2 & Account $(\%$ age $15+)$ & $\begin{array}{l}\text { Denotes the percentage of respondents, ages } 15+\text {, who report } \\
\text { having an account }\end{array}$ & $\mathrm{x} 2$ \\
\hline 3 & ATMs per 100,000 adults & $\begin{array}{l}\text { Denotes the total number of ATMs for every 100,000 adults } \\
\text { in the reporting country }\end{array}$ & x 3 \\
\hline 4 & Branches per 100,000 adults & $\begin{array}{l}\text { Denotes the number of branches of commercial banks for } \\
\text { every } 100,000 \text { adults in the reporting country }\end{array}$ & $\mathrm{x} 4$ \\
\hline 5 & Deposit accounts per 1,000 adults & $\begin{array}{l}\text { Denotes the total number of deposit accounts that are held } \\
\text { by resident nonfinancial corporations }\end{array}$ & x 5 \\
\hline 6 & POS terminals per 100,000 adults & $\begin{array}{l}\text { Denotes the number of point of sale (POS) terminals per } \\
100,000 \text { adults. }\end{array}$ & x 6 \\
\hline 7 & Outstanding loans per 1,000 adults & $\begin{array}{l}\text { Denotes the total number of loan accounts that are obtained } \\
\text { by resident nonfinancial corporations }\end{array}$ & $\mathrm{x} 7$ \\
\hline 8 & Used the internet (adults) & $\begin{array}{l}\text { Used the internet to pay bills or to buy something online in } \\
\text { the past year, older adults }(\% \text { age } 25+)\end{array}$ & x 8 \\
\hline 9 & $\begin{array}{l}\text { Credit card ownership, older } \\
\text { adults }(\% \text { age } 25+)\end{array}$ & $\begin{array}{l}\text { The percentage of respondents who report having a credit } \\
\text { card, older adults ( } \% \text { age } 25+)\end{array}$ & $\mathrm{x} 9$ \\
\hline 10 & $\begin{array}{l}\text { Made or received digital payments } \\
\text { in the past year, older adults ( } \% \\
\text { age } 25+)\end{array}$ & $\begin{array}{l}\text { The percentage of respondents who report using mobile } \\
\text { money, a debit or credit card, or a mobile phone to make a } \\
\text { payment from an account, or report using the internet to pay } \\
\text { bills or to buy something online, in the past } 12 \text { months, older } \\
\text { adults }(\% \text { age } 25+)\end{array}$ & $\mathrm{x} 10$ \\
\hline 11 & $\begin{array}{lll}\text { Contributory pensions } & \text { (Total } \\
\text { Population) } & & \\
\end{array}$ & Coverage of social insurance programs (\% of population) & Y1 \\
\hline 12 & $\begin{array}{l}\text { Social contributions }(\% \text { of } \\
\text { revenue })\end{array}$ & $\begin{array}{l}\text { Social contributions include social security contributions by } \\
\text { employees, employers, and self-employed individuals, and } \\
\text { other contributions whose source cannot be determined. } \\
\text { They also include actual or imputed contributions to social } \\
\text { insurance schemes operated by governments. }\end{array}$ & Y2 \\
\hline 13 & $\begin{array}{l}\text { Coverage of social protection and } \\
\text { labor programs ( } \% \text { of population) }\end{array}$ & $\begin{array}{l}\text { Coverage of social protection and labor programs (SPL) } \\
\text { shows the percentage of population participating in social } \\
\text { insurance, social safety net, and unemployment benefits and } \\
\text { active labor market programs. Estimates include both direct } \\
\text { and indirect beneficiaries. }\end{array}$ & Y3 \\
\hline 14 & $\begin{array}{l}\text { Unemployment, total }(\% \text { of total } \\
\text { labor force) }\end{array}$ & $\begin{array}{l}\text { Unemployment refers to the share of the labor force that is } \\
\text { without work but available for and seeking employment. }\end{array}$ & Y4 \\
\hline 15 & $\begin{array}{l}\text { Wage and salaried workers, total } \\
\text { (\% of total employment })\end{array}$ & $\begin{array}{l}\text { Wage and salaried workers (employees) are those workers } \\
\text { who hold the type of jobs defined as "paid employment jobs," } \\
\text { where the incumbents hold explicit (written or oral) or } \\
\text { implicit employment contracts that give them a basic } \\
\text { remuneration that is not directly dependent upon the revenue } \\
\text { of the unit for which they work. }\end{array}$ & Y5 \\
\hline 16 & $\begin{array}{l}\text { Coverage of social safety net } \\
\text { programs ( } \% \text { of population) }\end{array}$ & $\begin{array}{l}\text { Coverage of social safety net programs shows the percentage } \\
\text { of population participating in cash transfers and last resort } \\
\text { programs, noncontributory social pensions, other cash } \\
\text { transfers programs, conditional cash transfers, in-kind food } \\
\text { transfers and public works programs. }\end{array}$ & Y6 \\
\hline 17 & Cash transfers ( $\%$ of population) & $\begin{array}{l}\text { Coverage of social safety net programs shows the percentage } \\
\text { of population participating in cash transfers. }\end{array}$ & Y7 \\
\hline 18 & $\begin{array}{l}\text { Conditional cash transfer ( } \% \text { of } \\
\text { population) }\end{array}$ & $\begin{array}{l}\text { Coverage of social safety net programs shows the percentage } \\
\text { of population participating in conditional cash transfers. }\end{array}$ & Y8 \\
\hline
\end{tabular}


Index of socio-safety in the world

\begin{tabular}{|c|c|c|}
\hline Country & Income classification & Index \\
\hline Armenia & Upper middle income & 1,897 \\
\hline Bolivia & Lower middle income & 1,239 \\
\hline Burkina Faso & Low income & $-0,530$ \\
\hline Cameroon & Lower middle income & $-0,352$ \\
\hline Colombia & Upper middle income & 1,161 \\
\hline Costa Rica & Upper middle income & 1,606 \\
\hline Dominican Republic & Upper middle income & 0,651 \\
\hline El Salvador & Lower middle income & 1,100 \\
\hline Guatemala & Upper middle income & 1,179 \\
\hline Indonesia & Lower middle income & 1,198 \\
\hline Kazakhstan & Upper middle income & 1,562 \\
\hline Liberia & Low income & $-0,180$ \\
\hline Mauritania & Lower middle income & 1,085 \\
\hline Mexico & Upper middle income & 1,436 \\
\hline Montenegro & Upper middle income & 1,800 \\
\hline Mozambique & Low income & $-0,531$ \\
\hline Nicaragua & Lower middle income & 1,363 \\
\hline Niger & Low income & $-0,322$ \\
\hline Panama & High income & 1,462 \\
\hline Paraguay & Upper middle income & 1,339 \\
\hline Peru & Upper middle income & 1,173 \\
\hline Russian Federation & Upper middle income & 3,014 \\
\hline South Africa & Upper middle income & 2,240 \\
\hline Tanzania & Low income & $-0,297$ \\
\hline Turkey & Upper middle income & 1,443 \\
\hline Vietnam & Lower middle income & 0,427 \\
\hline
\end{tabular}

